\title{
RESEARCH PAPER \\ Tolerance of native Magellan fungi in peat to anthracene and n-dodecane for potential use in bioremediation
}

\author{
Leonardo A. Rodríguez-Córdovaㄹ, César A. Sáez-Navarrete ${ }^{1}$, Vartan \\ Ishanoglu ${ }^{2}$, Leandro Herrera ${ }^{3}$, and Rosanna Ginocchio ${ }^{4}$ \\ 'Departamento de Ingeniería Química y Bioprocesos, Escuela de Ingeniería, Pontificia Universidad Católica \\ de Chile. Ave. Vicuña Mackenna 4860, Macul, Santiago, Chile.
}

${ }^{2}$ Dirección de Responsabilidad Social, Escuela de Ingeniería, Pontificia Universidad Católica de Chile. Ave. Vicuña Mackenna 4860, Macul, Santiago, Chile.

${ }^{3}$ Departamento de Ingeniería Química y Biotecnología, Facultad de Ciencias Físicas y Matemáticas, Universidad de Chile, Beauchef 851, Santiago, Chile

${ }^{4}$ Departamento de Ecosistemas y Medio Ambiente, Facultad de Agronomía e Ingeniería Forestal, Pontificia Universidad Católica de Chile, Ave. Vicuña Mackenna 4860, Macul, Santiago, Chile.

\begin{abstract}
L.A. Rodriguez-Córdova, C.A. Sáez-Navarrete, V. Ishanoglu, L. Herrera, and R. Ginocchio. 2016. Tolerance of Magellan fungi in peat to anthracene and n-dodecane for potential use in bioremediation. Cien. Inv. Agr. 43(1):85-93. The tolerances of filamentous Magellan fungi in peat were analyzed in the presence of structurally different petroleum hydrocarbons to assess their abilities for bioremediation in contaminated soils. Fungi on PDA (potato dextrose agar) and fresh peat plates were cultured and purified. The morphologically identified species were grown in a hydrocarbon adapted-fungi (HAF) medium. Increasing concentrations of anthracene, $\mathrm{n}$-dodecane and furfural were applied to observe tolerances based on the radial growth kinetics of hyphae. The results showed that the radial growths of hyphae in anthracene reached average speeds of $10.95 \pm 1.21,11.03 \pm 3.14$ and $10.96 \pm 4.61 \mathrm{~mm} \mathrm{~h}^{-1}$ in $0.1,1$ and $2 \mathrm{~g} \mathrm{~L}^{-1}$ solutions, respectively. The average growth rates in $\mathrm{n}$-dodecane were 10.52 $\pm 3.33,14.67 \pm 1.88$ and $10.86 \pm 3.50 \mathrm{~mm} \mathrm{~h}^{-1}$ in 10,20 and $40 \mathrm{~g} \mathrm{~L}^{-1}$ solutions, respectively. The growth rate in furfural reached $3.95 \pm 1.07 \mathrm{~mm} / \mathrm{h}$ in a $5 \mathrm{~g} \mathrm{~L}^{-1}$ concentration. The results suggest that the identified filamentous fungi are tolerant to anthracene and n-dodecane, which are the primary components of petroleum fractions. Furfural, a recognized antifungal, limited the growth. The results also indicate hydrocarbon degradation, suggesting that Magellanic peat can be used as a potential inoculum in bioremediation treatment processes associated with petroleum-contaminated soils. The observed filamentous fungi belong to the Penicillium genus based on visual identification and $18 \mathrm{~S}$ rRNA.
\end{abstract}

Key words: Anthracene, contaminated sites, filamentous fungi, furfural, Magellan peat, n-dodecane 


\section{Introduction}

The intensive use of petroleum fuels has been the basis for industrial development since the nineteenth century. Projections for 2035 indicate that fossil fuels may provide $80 \%$ of the world energy needs (OPEC Secretariat, 2013). However, massive crude oil extraction processes, the production of hydrocarbon compounds derived from refining operations, oil storage and fuel transportation have resulted in spills and emissions that introduce xenobiotics, toxic and hazardous chemicals into the biosphere. Many of these toxins are highly persistent in aquatic and terrestrial environments (Blinova et al., 2012). To reduce these impacts, countries have developed increasingly strict environmental and operational regulations as well as more efficient and effective control strategies for spills and emissions (Deuel et al., 2005). These strategies have improved production processes and existing technologies. Additionally, several technologies have been employed to remediate petroleum-contaminated soils. Among these technologies, those based on the use of native microorganisms grown at the impacted site have become particularly popular (Godoy-Faúndez et al., 2008; Sáez-Navarrete et al., 2008). The idea behind this method is to prevent the introduction of new competitor species, which may jeopardize the biological balance of the soil; therefore, the method uses native species that are adapted to the environmental conditions of the site and, in many cases, to the contaminants (El Fantroussi and Agathos, 2005).

Sources for obtaining these microorganisms are diverse, but organic substrates are preferred due to their ecological diversity (Godoy-Faúndez et al. 2008; Sáez-Navarrete et al., 2008). In such substrates, complex microecosystems formed by bacteria, fungi, yeast, actinomycetes and microalgae can be identified. These constituents can potentially transform contaminants into less hazardous chemicals or even to carbon dioxide (Beškoski et al., 2012). Peatlands are included among these microecosystems. Peat is a spongy, carbon-rich organic matter that is produced by the decomposition and fossilization of plant material (Sáez-Navarrete et al., 2008). Its characteristics vary spatially and depend on the local plant species, representing a rich biological stratification (Bragina et al., 2014).

In Chile, peatlands are concentrated in the south of the country, encompassing a total area of $10,470 \mathrm{~km}^{2}$. The most common peatland type is found in Chilean Patagonia, covering a total of 90,000 ha (MMA, 2015). The dominant species is sphagnum moss, which has been previously used as a bulking material and nutrient source for contaminant degraders in remediation studies of petroleum-contaminated soils (Sáez-Navarrete et al., 2008). Microorganism studies near Chilean Patagonia and Antarctica have noted that Magellanic peat can potentially be used to treat petroleum hydrocarbon contamination (Vazquez et al., 2013) in cold regions and also in situ. Some species of filamentous fungi present in Magellanic peat may be able to not only tolerate complex carbon-based compounds but also mineralize and biodegrade them, as has been described for other substrates (Antízar-Ladislao et al., 2004).

The purpose of this study is to identify native Magellanic fungi in peat that are tolerant to anthracene, n-dodecane and furfural and possess potential for degradation and bioremediation in contaminated soils.

\section{Materials and methods}

\section{Fungal strains and hydrocarbon selection}

Fresh peat was extracted from the Magallanes Region and the subantarctic territory (Punta Arenas, 5309'00" S, 7055'00” W). The samples were obtained at 20 to $30 \mathrm{~cm}$ depth using sterile and airtight plastic bags. The samples were transported in cold medium to later perform growth testing in the presence of the contaminants of interest. Based on the methodology described 
by Hughes et al. (2007), two peat samples were collected ( $0.35 \mathrm{~g}$ wet weight each) and placed in dextrose saturated water $(10 \mathrm{~mL})$ in Petri dishes in triplicate (6 plates). Plates were incubated for 15 days at $28 \pm 2{ }^{\circ} \mathrm{C}$, allowing enough time for the growth of filamentous fungi. Incubation was performed in the dark at a relative humidity of $17 \pm 2 \%$.

The developed hyphae samples were placed in Petri plates with potato dextrose agar (PDA) and antibiotics. The plates were incubated at $28 \pm 2$ ${ }^{\circ} \mathrm{C}$ for 20 days. Preliminary identification of the filamentous fungi was performed using a Motic ${ }^{\circledR}$ BA310 optical microscope based on the descriptions of their morphological characteristics.

Anthracene, furfural and n-dodecane were chosen as the selected contaminants. $\mathrm{N}$-dodecane was used as a representative of biodegradable alkanes. Furfural was used as a representative of heterocyclic aromatic hydrocarbons. Anthracene was selected as a representative of low molecular weight PAHs due to its hazardous toxic characteristics (United States Environmental Protection Agency, 2006). Sigma-Aldrich brand reagents were used in the analysis, including furfural CAS No. 98-01-01 (99\%), anthracene CAS No. 120-12-7 (99\%) and n-dodecane CAS No. 112-40-3 (99\%).

\section{Tolerance tests}

To establish the tolerance of the fungal species, hydrocarbon-adapted fungi (HAF) (Elshafie et al., 2007) were used in sterile Petri dishes. The basal components of the HAF medium consist of $250 \mathrm{mg} \mathrm{L}^{-1}$ of $\mathrm{KCl}, 1 \mathrm{~g} \mathrm{~L}^{-1}$ of $\mathrm{NaH}_{2} \mathrm{PO}_{4}, 1 \mathrm{~g} \mathrm{~L}^{-1}$ of $\mathrm{NH}_{4} \mathrm{NO}_{3}$ and $15 \mathrm{~g} \mathrm{~L}^{-1}$ of agar. A contaminant was then added to each medium. HAF plates without contaminants were used as controls.

All selected hydrocarbons were used at concentrations of $0.1,1$ and $10 \mathrm{~g} \mathrm{~L}^{-1}$, respectively. Experiments were performed in triplicate. A HAF medium with agar as the sole carbon source was used as a control. Initially, Petri dishes contained the HAF media plus contaminants at the concentrations indicated above. The plates were filled to half their volumetric capacities. Subsequently, 0.35 $\mathrm{g}$ of peat was placed on each plate. The plates were developed at $28 \pm 2^{\circ} \mathrm{C}$ for 15 days in the dark to allow fungal growth. A subculture with observable hyphae was then created. To do so, the same HAF media and selected contaminants in the concentrations indicated above were used as purifying mechanisms of tolerant strains. In this subculture, radial growth and morphological characteristics were observed under a microscope.

\section{Tolerant fungal strains}

After tolerance testing, hyphae were removed to carry out genetic characterization of those fungal species developed in the experiment, using $18 \mathrm{~S}$ rRNA (Nishida and Sugiyama, 1993).

\section{Statistical analyses}

The differences in the radial growth in each condition studied (treatment) were evaluated by two-way ANOVA using time and treatment as factors (Akbari and Ghoshal, 2014). A statistical analysis was performed using Minitab software with $\alpha=0.05$. Normality, independence and homoscedasticity of the data were also verified.

\section{Results and discussion}

\section{Fungi observations}

After the initial incubation, hyphal growth in peat (Figure 1a) was observed. These hyphae quickly colonized the plates where they were inoculated (Figure 1b), covering 100\% of the available surface in two days (Figure 1c).

Samples were extracted from the fully colonized Petri dishes to be identified using conventional optical 
microscopy. Morphological characterization showed a single type of strain with characteristics similar to those of Penicillium. Conidiophores (main stem), metulae (outer branch) and spores were observed, and phialides formed at the end of the conidiophores and metulae (sporulation area shaped like a brush). These observations are consistent with Penicillium. Furthermore, a teal color, which is characteristic of this genus, was described. No other strains were observed under the microscope.

After analyzing the characteristics of this filamentous fungus, they were compared to microscopic images of filamentous fungi of Penicillium available in the literature. This comparison confirmed the initial hypothesis regarding the presence of this species (Figure 2).

While Penicillium is common in temperate environments, it has also adapted to very cold areas. Indeed, samples obtained for this study were obtained from peatlands located in Patagonia and in the subantarctic territory of Chile. This fungal species has also been identified in Magellan soils contaminated with petroleum and petroleum products (Balaji et al., 2014), in which its degradative potential has been described. This species produces cellulases, which are nonspecific enzymes capable of degrading complex compounds such as cellulose via osmotrophy (Harms et al., 2011).

\section{Strain tolerance}

Controlled fungal cultures and treatments are shown in Figure 3. The availability of the sole carbon source, agar-agar, promoted radial growth at an average of $6.89 \pm 2.09 \mathrm{~mm} \mathrm{~h}^{-1}$ (control). The lag phase observed is $15 \mathrm{~h}$.

The experiments using HAF, anthracene, dodecane and furfural exhibited growth rates within
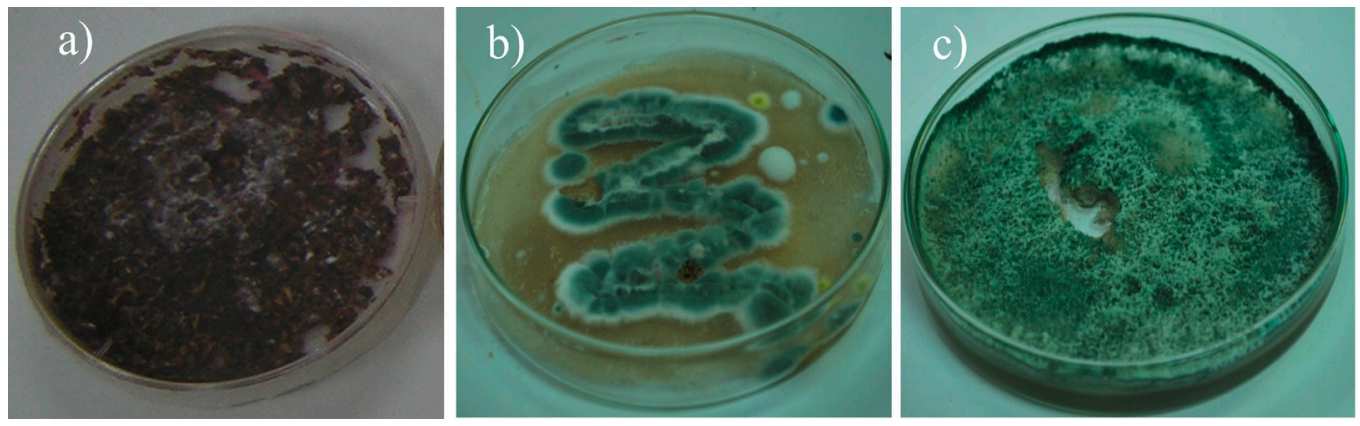

Figure 1. a. Fungal growth in peat. b. Fungi isolated from peat in a PDA medium (Potato Dextrose Agar) with antibiotics. c. Complete fungal colonization of the Petri dish.
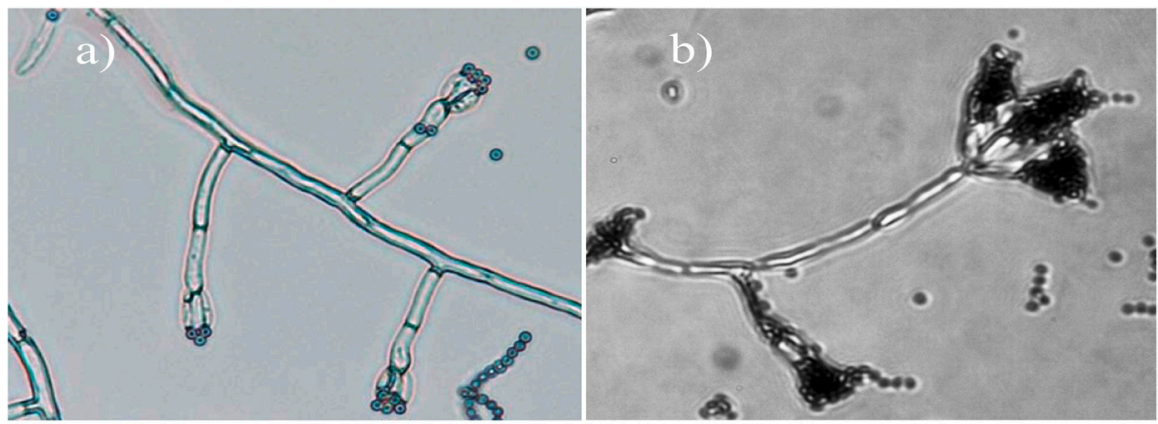

Figure 2. a. Microscopic image of Penicillium sp. SA29 (Ohashi et al., 2008). b. Microscopic image (40x) of filamentous fungi obtained from Magellan peat. 
normal ranges. The radial growth for $5 \mathrm{~g} \mathrm{~L}^{-1}$ of furfural displayed an average speed of 3.95 $\pm 1.07 \mathrm{~mm} \mathrm{~h}^{-1}$ (Figure 3). Furfural is a known commercial antifungal and antibacterial organic compound that has been associated with a strong antibiotic action and a lesser antifungal action at a concentration of $1 \mathrm{mM}\left(0.096 \mathrm{~g} \mathrm{~L}^{-1}\right)$ (Kurita et al., 1981). These results suggest that a furfural concentration of $10 \mathrm{~g} \mathrm{~L}^{-1}$ was necessary to inhibit fungi growth.

Growth kinetics observed for dodecane (ndodecane) were significantly higher than those of the control $(\mathrm{P}=0.009)$, reaching average growth speeds of $10.52 \pm 3.33,14.67 \pm 1.88$ and $10.86 \pm$ $3.50 \mathrm{~mm} \mathrm{~h}^{-1}$ for concentrations of 10,20 and $40 \mathrm{~g}$ $\mathrm{L}^{-1}$, respectively. The stereochemical structure of $\mathrm{n}$-dodecane is susceptible to single bond attacks by nonspecific enzymatic activity associated with the fungi, which is able to degrade complex organic compounds such as cellulose, hemicellulose and lignin (Harms et al., 2011). This molecular struc- ture makes it more metabolically assimilable than the polysaccharides present in agar (Figure 3). No significant differences were observed among the three $n$-dodecane concentrations tested $(\mathrm{P}=0.186)$.

The growth kinetics observed for anthracene were significantly higher than those of the control $(\mathrm{P}=0.003)$, reaching average growth speeds of 10.95 $\pm 1.21,11.03 \pm 3.14$ and $10.96 \pm 4.61 \mathrm{~mm} \mathrm{~h}^{-1}$ for concentrations of $0.1,1$ and $2 \mathrm{~g} \mathrm{~L}^{-1}$, respectively (Figure 3). Although significant differences among the tested anthracene concentrations $(\mathrm{P}=0.227)$ were not observed, the observed kinetics were found to be greater than those of the control.

Neither the growth in plates supplemented with the linear alkane nor in those supplemented with anthracene showed significant differences at the concentrations used $(\mathrm{P}=0.330)$. In fact, significant differences were not observed with increases of either organic compound, suggesting that the maximum fungal growth rates were reached for
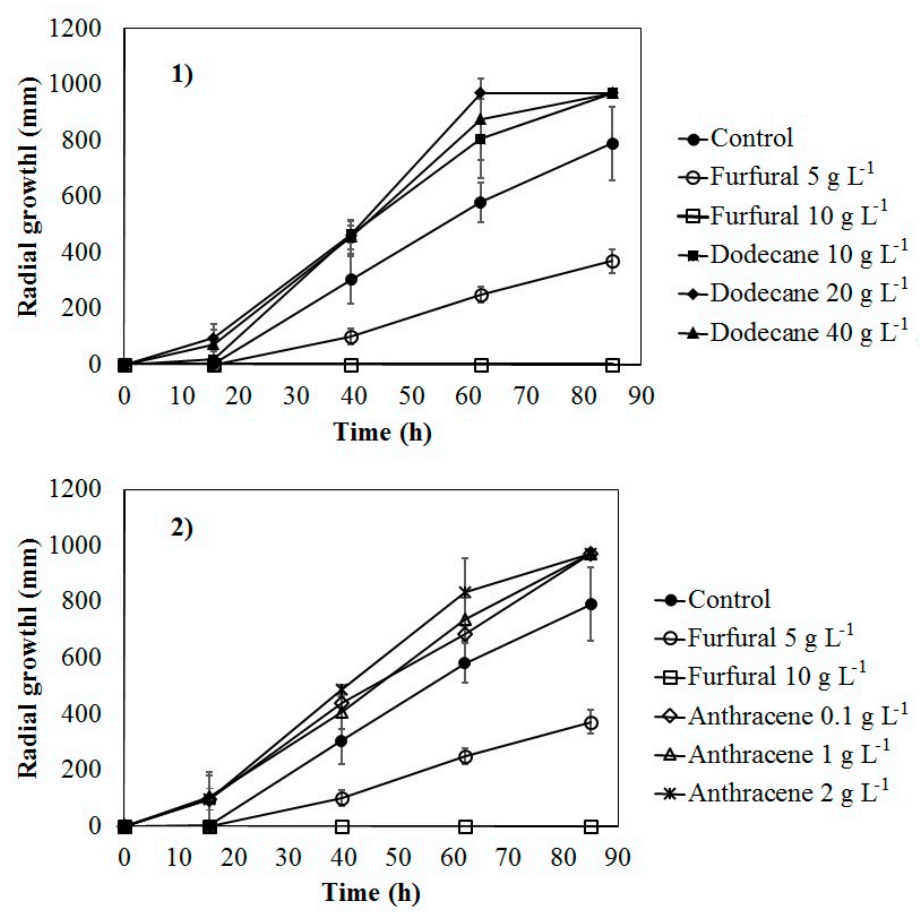

Figure 3. The average radial growth of Penicillium on the control and furfural plates (5 and $\left.10 \mathrm{~g} \mathrm{~L}^{-1}\right)$ compared to: (1) Dodecane plates (10, 20 and $\left.40 \mathrm{~g} \mathrm{~L}^{-1}\right)$ and (2) Anthracene plates $\left(0.1,1\right.$ and $\left.2 \mathrm{~g} \mathrm{~L}^{-1}\right)$. Standard deviations of each group of three repetitions are included. 
the carbon sources used (n-dodecane and furfural). Toxic and inhibitory effects were not observed at the concentrations tested.

The fungal species tested can tolerate high concentrations of n-dodecane and anthracene, which are both known to be highly toxic. Based on the observed kinetics, it is likely that both hydrocarbons were biodegraded by the fungal species. However, based on the experimental design and focus, the fraction of each hydrocarbon species that was degraded cannot be precisely determined with respect to the carbon source in the HAF medium, which was used as a control.

\section{Identification of tolerant fungal strains}

Genetic characterization based on 18S r-RNA identified the fungi as Penicillium. Three species of this genus were found. The fungus strains belong to the species Penicillium purpurogenum, Penicillium rugulosum and Penicillium variabile (Figure 4). Penicillium purpurogenum has been studied because of its metabolites and potential industrial applications, as its enzymatic process can be used in the production of biodiesel (Gusakov and Sinitsyn, 2012). Penicillium rugulosum has been found in arctic soils, and its enzymatic metabolism involves pectinases and cellulases

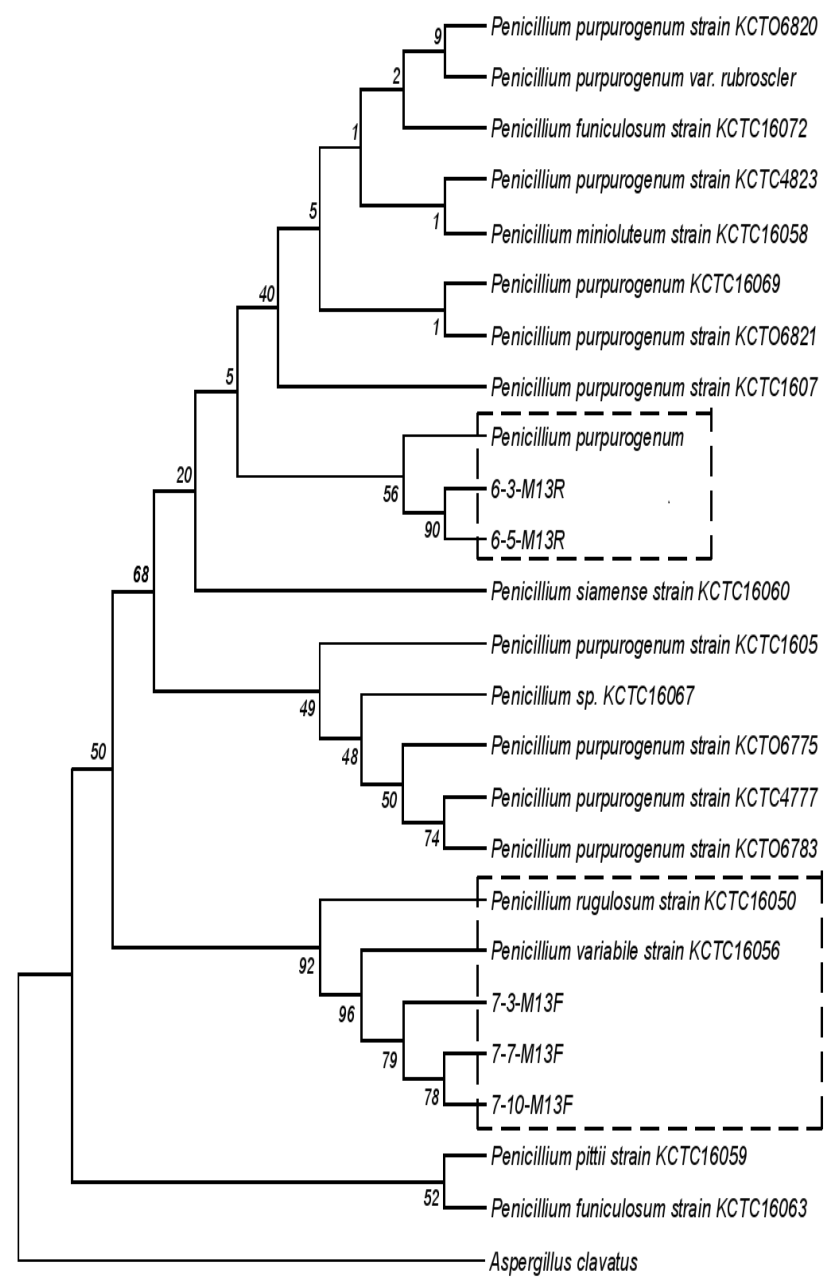

Figure 4. Phylogeny of Penicillium identified in Magellan peat. 
(Gawas-Sakhalkar and Singh, 2011). Penicillium variabile has been studied in the context of phytohormone production (Isa and Don, 2014) and due to its gallotannin metabolism (tannase) (Sharma et al., 2008).

The genus Penicillium is known for its ability to degrade lignocellulosic materials (Leitão, 2009). Additionally, it is not surprising to find Penicillium in Magellan peat in a subantarctic area, as extremophile species of this fungus have been previously identified in cold regions (Gunde-Cimerman et al., 2003). The presence of this type of microorganism in a region that has been extensively contaminated by oil extraction since the early twentieth century is beneficial for feasibility programs targeting bioremediation at these contaminated sites.

We conclude that the fungal species identified and tested can tolerate high concentrations of n-dodecane and anthracene, which are known toxins. Additionally, in terms of the observed kinetics, it is likely that both hydrocarbons are biodegraded by the fungal species studied. However, this experimental design focused on determining tolerance. Therefore, the degraded fractions of each hydrocarbon species cannot be precisely determined with respect to the carbon source contained in the HAF medium (control). The identification of these strains as Penicillium species demonstrates the degradation potentials of the compounds tested, which should be further studied using Magellan peat as an inoculum.

\section{Acknowledgments}

This research was partly supported by the National Commission for Scientific and Technological Research (CONICYT) of the Chilean Government via a doctoral scholarship awarded to Leonardo Rodríguez-Córdova (No. 21,090,472). Thank you for your important contribution.

We thank the Laboratory of Biochemistry, Department of Molecular Genetics and Microbiology, Pontificia Universidad Católica de Chile, led by Professor Patricio Arce, who made an exceptional contribution to the genetic characterization tests.

We also thank Professor Loreto Muñoz, Microscopy Laboratory, Department of Chemistry and Bioprocess Engineering, Pontificia Universidad Católica de Chile, for her kind and experienced assistance regarding the optical microscopy images presented in this article.

\section{Resumen}

L.A. Rodríguez-Córdova, C.A. Sáez-Navarrete, V. Ishanoglu, L. Herrera y R. Ginocchio. 2016. Tolerancia a antraceno y n-dodecano de hongos nativos de turba Magallánica para su potencial uso en biorremediación. Cien. Inv. Agr. 43(1):85-93. Se estudia la tolerancia de hongos filamentosos de turba magallánica en presencia de hidrocarburos derivados del petróleo estructuralmente diferentes, con miras a ser empleados como agentes de biorremediación de suelos contaminados. Se cultivaron y purificaron hongos en placas con PDA (Agar de Papa y Dextrosa) y turba fresca. Las especies morfológicamente identificadas se cultivaron en medio HAF (Hidrocarbon Adapted-Fungi) con concentraciones crecientes de antraceno, n-dodecano y furfural para observar su tolerancia a través de las cinéticas de crecimiento radial de hifas. Los resultados muestran que el crecimiento radial de las hifas en antraceno alcanzó una velocidad media de $10.95 \pm 1.21,11.03 \pm 3.14$, y $10.96 \pm 4.61 \mathrm{~mm} \mathrm{~h}^{-1}$ para concentraciones de $0.1,1$ у 2 $\mathrm{g} \mathrm{L}^{-1}$; para n-dodecano las velocidades medias alcanzaron los $10.52 \pm 3.33,14.67 \pm 1.88$ y 10.86 $\pm 3.50 \mathrm{~mm} \mathrm{~h}^{-1}$ para 10,20 y $40 \mathrm{~g} \mathrm{~L}^{-1}$. Ensayos con furfural alcanzaron $3.95 \pm 1.07 \mathrm{~mm} \mathrm{~h}^{-1}$ a 5 $\mathrm{g} \mathrm{L}^{-1}$. Los resultados muestran que el hongo filamentoso identificado es tolerante a antraceno 
y n-dodecano, constituyentes característicos de fracciones del petróleo. Por su parte furfural, reconocido antifúngico, limita el crecimiento. Los resultados también muestran degradación de los compuestos señalados posicionando a la turba Magallánica como potencial contribuyente de inóculos para procesos de biorremediación de suelos contaminados con hidrocarburos del petróleo. Se identificó el género Penicillium como el hongo filamentoso desarrollado mediante identificación visual y $18 \mathrm{~S}$ RNA.

Palabras clave: Antraceno, furfural, hongos filamentosos, n-dodecano, sitios contaminados, turba Magallánica.

\section{References}

Akbari, A., and S. Ghoshal. 2014. Pilot-scale bioremediation of a petroleum hydrocarbon-contaminated clayey soil from a sub-Arctic site. Journal of Hazardous Materials 280: 595-602.

Antizar-Ladislao, B., J.M. Lopez-Real, and A.J. Beck. 2004. Bioremediation of polycyclic aromatic hydrocarbon (PAH)-contaminated waste using composting approaches. Critical Reviews in Environmental Science and Technology 34: 249-289.

Balaji, V., P. Arulazhagan, and P. Ebenezer. 2014. Enzymatic bioremediation of polyaromatic hydrocarbons by fungal consortia enriched from petroleum contaminated soil and oil seeds. Journal of Environmental Biology 35: 521-529.

Beškoski, V., G. Gojgić-Cvijović, J. Milić, M. Ilić, S. Miletić, B. Jovančićević, and M. Vrvić. 2012. Bioremediation of soil polluted with crude oil and its derivatives: microorganisms, degradation pathways, technologies. Hemijska Industrija. 66: 275-289.

Blinova, I., L. Bityukova, K. Kasemets, A. Ivask, A. Kaekinen, I. Kurvet, O. Bondarenko, L. Kanarbik, M. Sihtmaee, V. Aruoja, H. Schvede, and A. Kahru 2012. Environmental hazard of oil shale combustion fly ash. Journal of Hazardous Materials 229: 192-200.

Bragina, A., L. Oberauner-Wappis, C. Zachow, B. Halwachs, G.G. Thallinger, H. Müller, and G. Berg. 2014. The Sphagnum microbiome supports bog ecosystem functioning under extreme conditions. Molecular ecology 23: 4498-4510.
Deuel, L.E., Jr., and G.H. Holliday. 2005. Evolution of oil and gas waste/soil remediation regulations. ASME 2005 International Mechanical Engineering Congress and Exposition 61-67.

El Fantroussi, S., and S. Agathos. 2005. Is bioaugmentation a feasible strategy for pollutant removal and site remediation? Current Opinion in Microbiology 8: 268-275.

Elshafie, A., A.Y. AlKindi, S. Al-Busaidi, C. Bakheit, and S.N. Albahry. 2007. Biodegradation of crude oil and n-alkanes by fungi isolated from Oman. Marine Pollution Bulletin 54: 1692-1696.

Gawas-Sakhalkar, P., and S.M. Singh. 2011. Fungal community associated with Arctic moss, Tetraplodon mimoides and its rhizosphere: bioprospecting for production of industrially useful enzymes. Current Science 100: 17011705.

Godoy-Faundez, A., B. Antizar-Ladislao, L. ReyesBozo, A. Camano, and C. Saez-Navarrete. 2008. Bioremediation of contaminated mixtures of desert mining soil and sawdust with fuel oil by aerated in-vessel composting in the Atacama Region (Chile). Journal of Hazardous Materials 151: 649-657.

Gunde-Cimerman, N., S. Sonjak, P. Zalar, J.C. Frisvad, B. Diderichsen, and A. Plemenitaš. 2003. Extremophilic fungi in arctic ice: a relationship between adaptation to low temperature and water activity. Physics and Chemistry of the Earth, Parts A/B/C 28: 1273-1278.

Gusakov, A.V., and A.P. Sinitsyn 2012. Cellulases from Penicillium species for producing fuels from biomass. Biofuels 3: 463-477. 
Harms, H., D. Schlosser, and L. Wick. 2011. Untapped potential: exploiting fungi in bioremediation of hazardous chemicals. Nature reviews 9: 177-192.

Hughes, K.A., P. Bridge, and M.S. Clark. 2007. Tolerance of Antarctic soil fungi to hydrocarbons. Science of the Total Environment 372: 539-548.

Isa, N.K.M., and M M. Don. 2014. Investigation of the gibberellic acid optimization with a statistical tool from Penicillium variable in batch reactor. Preparative Biochemistry \& Biotechnology 44: 572-585.

Kurita, N., M. Miyaji, R. Kurane, and Y. Takahara. 1981. Antifungal activity of components of essential oils. Agricultural and Biological Chemistry 45: 945-952.

Leitão, A.L. 2009. Potential of Penicillium species in the bioremediation field. International Journal of Environmental Research and Public Health 6: 1393-1417.

Ministerio del Medio Ambiente de Chile (MMA). 2015. Turberas en la Patagonia Austral. From http://www.mma.gob.cl/1304/w3-article-55824. html. Accessed on January 19, 2016.

Nishida, H., and J. Sugiyama. 1993. Phylogenetic-relationships among Taphrina, Saitoella, and other higher fungi. Molecular Biology and Evolution 10: 431-436.
Ohashi, K., Y. Miyagawa, Y. Nakamura, and H. Shibuya. 2008. Bioproduction of bile acids and the glycine conjugates by Penicillium fungus. Journal of Natural Medicines 62: 83-86.

Saez-Navarrete, C., C. A. Gelmi, L. Reyes-Bozo, and A. Godoy-Faundez 2008. An exploratory study of peat and sawdust as enhancers in the (bio) degradation of n-dodecane. Biodegradation 19: 527-534.

OPEC Secretariat. 2013. World Oil Outlook, 2013. Vienna, Austria. 347 pp.

Sharma, S., L. Agarwal, and R.K. Saxena. 2008. Purification, immobilization and characterization of Tannase from Penicillium variable. Bioresource Technology 99: 2544-2551.

United States Environmental Protection Agency, Pesticide and Toxic Substances (7501P). 2006. Pesticide fact sheet. From

http://www.epa.gov/opp00001/chem_search/reg_actions/registration/fs_PC-043301_01-Sep-06.pdf. Accessed on July 27, 2015.

Vazquez, S., B. Nogales, L. Ruberto, C. Mestre, J. Christie-Oleza, M. Ferrero, R. Bosch, and W. P. Mac Cormack. 2013. Characterization of bacterial consortia from diesel-contaminated Antarctic soils: Towards the design of tailored formulas for bioaugmentation. International Biodeterioration \& Biodegradation 77: 22-30. 
